Interactive comment on "Measurement of $\mathrm{NO}_{x}$ and $\mathrm{NO}_{y}$ with a thermal dissociation cavity ring-down spectrometer (TD-CRDS): Instrument characterisation and first deployment" by Nils \title{
Friedrich et al.
}

Nils Friedrich et al.

nils.friedrich@mpic.de

Received and published: 17 August 2020

The comment was uploaded in the form of a supplement:

https://amt.copernicus.org/preprints/amt-2020-187/amt-2020-187-AC1-

supplement.pdf 